\title{
PERCEPÇÕES DOS PROFESSORES DE UMA ESCOLA DA REDE PÚBLICA DO DISTRITO FEDERAL SOBRE A AVALIAÇÃO NACIONAL DA ALFABETIZAÇÃO (ANA)
}

\author{
PERCEPTIONS OF TEACHERS AT A PUBLIC SCHOOL \\ IN THE FEDERAL DISTRICT ABOUT THE NATIONAL \\ LITERACY ASSESSMENT (ANA)
}

PERCEPCIONES DE LOS MAESTROS EN UNA ESCUELA PÚBLICA EN EL DISTRITO FEDERAL SOBRE LA EVALUACIÓN NACIONAL DE ALFABETIZACIÓN (ANA)

\author{
Thamara Maria De Souza ${ }^{\mathrm{I}}$ \\ ROBSON DIAS $^{\mathrm{I}}$ \\ ${ }^{\text {I } U n i v e r s i d a d e ~ C a t o ́ l i c a ~ d e ~ B r a s i ́ l i a ~(U C B), ~ B r a s i ́ l i a / D F ~-~ B r a s i l ~}$
}

RESUMo Este artigo teve por objetivo analisar como a Avaliação Nacional da Alfabetização (ANA) é percebida pelos professores do Bloco Inicial de Alfabetização (BIA) de uma escola classe da rede pública de ensino do Distrito Federal (DF). Para o estudo foi realizada uma pesquisa básica, exploratória com abordagem qualitativa. Para compor a pesquisa foram coletados dados por meio de questionário com os professores do BIA e entrevista com um membro da equipe diretiva. Considerando o objetivo da ANA de inserir-se no BIA numa perspectiva de avaliar para redirecionar o processo de ensino-aprendizagem em sala de aula e, também de induzir a produção de políticas educacionais voltadas à melhoria da qualidade da alfabetização no país, os resultados da pesquisa indicam, na percepção dos professores que atuam nas classes de alfabetização da escola pesquisada, a existência de um distanciamento entre o objetivo a que se propunha a ANA e a sua prática real.

Palavras-chave: Políticas Públicas Educacionais. Avaliação Nacional da Alfabetização. Bloco Inicial de Alfabetização. Distrito Federal.

ABSTRACT This article aimed to analyze how the National Literacy Assessment (ANA) is perceived by teachers in the Initial Literacy Block (BIA) of a public school in the Federal District (DF). For the study, a basic, exploratory research was carried out with a qualitative approach. To compose the research, data were collected through a questionnaire with BIA professors and an interview with a member of the management team. Considering the 
purpose of ANA to enter the BIA in a perspective of evaluating to redirect the teachinglearning process in the classroom, and also to induce the production of educational policies aimed at improving the quality of literacy in the country, the results of Research indicates, in the perception of teachers who work in the literacy classes of the school researched, the existence of a distance between the objective proposed by ANA and its real practice.

Keywords: Public Educational Policies. National Literacy Assessment. Initial LiTERACy Block. Federal District.

RESUMEN Este artículo tuvo como objetivo analizar cómo los maestros perciben la Evaluación Nacional de Alfabetización (ANA) en el Bloque de Alfabetización Inicial (BIA) de una escuela pública en el Distrito Federal (DF). Para el estudio, se realizó una investigación exploratoria básica con un enfoque cualitativo. Para componer la investigación, los datos se recopilaron mediante un cuestionario con profesores de BIA y una entrevista con un miembro del equipo de gestión. Considerando el propósito de ANA para ingresar al BIA en una perspectiva de evaluación para redirigir el proceso de enseñanza-aprendizaje en el aula, y también para inducir la producción de políticas educativas destinadas a mejorar la calidad de la alfabetización en el país, los resultados de La investigación indica, en la percepción de los docentes que trabajan en las clases de alfabetización de la escuela investigada, la existencia de una distancia entre el objetivo propuesto por ANA y su práctica real.

Palabras clave: Políticas educativas públicas. Evaluación Nacional de Alfabetización. Bloque de Alfabetización Inicial. Distrito Federal.

\section{INTRODUÇÃo}

Este estudo busca analisar em uma escola da rede pública de ensino do Distrito Federal (DF) como a Avaliação Nacional da Alfabetização (ANA), atualmente conhecida por SAEB, é percebida pelos professores do Bloco Inicial de Alfabetização (BIA). Cabe ressaltar que no período de realização desta pesquisa, novembro de 2018, a ANA foi extinta e passou a ser denominada de SAEB. Foram realizadas as seguintes mudanças a partir do ano de 2019:

- Conforme a resolução CNE $n^{\circ}$ 2, de 22/12/2017 da Base Nacional Curricular Comum (BNCC) serão implementadas novas Matrizes de Língua Portuguesa e Matemática tendo o $2^{\circ}$ ano do Ensino Fundamental, Anos Iniciais, como etapa de referência.

- A população-alvo passa a ser o $2^{\circ}$ ano do EF.

- A aplicação dos testes passa a ser mediada por um aplicador de perfil especializado, semelhante ao de professores do $2^{\circ}$ ano do Ensino Fundamental, Anos Iniciais.

- Há previsão de itens de resposta construída tanto para Língua Portuguesa quanto para Matemática. Em 2020, serão utilizados novos descritores de proficiência para o $2^{\circ}$ ano do Ensino Fundamental, Anos Iniciais.

- Haverá a possibilidade de adesão facultada a quaisquer escolas particulares que ofereçam as etapas avaliadas, mediante recolhimento de valor. 
- A aplicação ocorrerá em anos ímpares (2019-2021) e a divulgação dos resultados e indicadores em anos pares $(2020-2022)$.

Fonte: http://portal.inep.gov.br/web/guest/inicio. Acesso em 13/11/18

A análise e discussão dos dados empíricos foi alinhada ao quadro teórico, aos objetivos, à problemática e aos procedimentos metodológicos da pesquisa. Para o tratamento das informações coletadas foi realizada Análise Textual Discursiva (MORAES, 2003).

Empregou-se como alicerce das categorias de análise os operadores cognitivos do pensamento complexo (MARIOTTI, 2007). Os operadores cognitivos "são instrumentos conceituais que facilitam a compreensão e a prática do pensamento complexo" (MARIOTTI, 2007, p. 138). Sua utilização possibilita o diálogo entre o pensamento linear, cartesiano, e o pensamento sistêmico, circular (MARIOTTI, 2007).

O artigo está organizado em 4 (quatro) partes, além desta introdução. Na primeira parte, é apresentado, brevemente, as possibilidades e as limitações da prática pedagógica da ANA no BIA. Na segunda parte estão descritos o locus e os sujeitos da pesquisa. Na terceira parte são analisados e discutidos os dados empíricos de como a ANA é percebida pelos professores no BIA em uma escola da rede pública de ensino do Distrito Federal. Por fim, na quarta parte são apresentadas as considerações finais.

\section{BLOCO INICIAL DE ALFABETIZAÇÃo: POSSIBILIDADES E LIMITES DA PRÁtiCA PEDAGógiCA da AVALIAÇÃo NACIONAL DA ALFABETIZAÇÃo}

A Avaliação Nacional da Alfabetização (ANA) se caracteriza por um processo de avaliação externa que tem como ponto de partida e de chegada a prática pedagógica. Ela fornece informações que apontam onde estão as dificuldades do processo de alfabetização, ou seja, as condições de oferta do Bloco Inicial de Alfabetização (BIA) para que possam ser definidas estratégias e ações de enfrentamento destas situações. Essa reflexão sobre a realidade educacional tanto no âmbito local quanto na esfera dos sistemas permite aos gestores e educadores tomarem decisões acerca das intervenções necessárias à garantia da aprendizagem dos estudantes.

Essa discussão sobre a qualidade do ensino e da educação suscita o diálogo entre todos os profissionais que atuam e participam do contexto escolar, incluindo as famílias dos estudantes. "Neste cenário, o professor ocupa posição de destaque na mediação entre os saberes científicos e a comunidade. É um ator que age junto aos sujeitos da educação e, por vezes, constitui-se no polo de referência política, social e escolar" (SOLIGO, 2010, p. 119). Nesse sentido, enquanto ator político-social, o professor torna-se responsável por atuar como agente de mudança e de inovação do sistema educacional, ou simplesmente por manter e reproduzir estruturas cristalizadas (SOLIGO, 2010).

Esta prática reflexiva cotidiana do professor implica na adoção de uma postura investigativa na qual ele busque continuamente questionar não apenas sua prática, mas também as políticas educacionais que contribuem ou não para o sucesso de sua atuação. Sabe-se da impossibilidade em se responder a todas as indagações que surgem em virtude da implementação da ANA bem como em relação às suas possibilidades e limites, tais como: A ANA 
tem contribuído para o desenvolvimento de uma cultura avaliativa na escola? A ANA tem estimulado a melhoria do processo de alfabetização? O que pensam os professores sobre esta política? Os professores utilizam os indicadores produzidos pela ANA em prol da melhoria da aprendizagem de seus estudantes? Qual a relevância desta política para o professor?

No entanto, percebe-se como um caminho possível e viável apontar como reflexão "a necessidade de consciência e responsabilidade do professor para o conhecimento do contexto e da realidade escolar, das necessidades específicas da comunidade na qual está inserido e das políticas públicas nacionais ou locais" (SOLIGO, 2010, p. 123). Tendo em vista que, diante desses e de tantos outros questionamentos que surgem em meio a prática cotidiana docente, a reflexão, o diálogo e o trabalho em conjunto, constituem-se em importantes elementos na busca pela qualidade da educação. Sabe-se que as avaliações em qualquer nível (da aprendizagem, institucional ou de larga escala) só "adquirem significação quando seus processos e resultados são abertos e trabalhados como construção e diagnóstico de parte da realidade da escola" (SOLIGO, 2010, p. 124).

Entende-se que a prática pedagógica no BIA não é única e, exclusivamente condicionada pela ANA, mas admite-se que esta pode exercer uma certa influência direta ou indireta sobre tal prática. A SEEDF possui um currículo que norteia o trabalho pedagógico a ser desenvolvido no $2^{\circ}$ Bloco do $2^{\circ}$ ciclo da organização escolar em ciclos para as aprendizagens. Denominado Currículo em Movimento para Educação Básica. Os objetivos e conteúdos propostos, especificamente, para o BIA em Língua Portuguesa estão organizados de forma a atender as seguintes áreas: leitura; produção escrita e oral; conhecimentos linguísticos articulados com os textos; e literatura. Em Matemática, os conteúdos e objetivos estão divididos em blocos: números e operações; espaço e forma; grandezas e medidas; e tratamento das informações (SEEDF, s/d, p.68).

Portanto, "ainda que se admita a influência das avaliações sobre o currículo de fato praticado nas escolas, o professor está envolto num contexto mais amplo, onde escolhas internas e interferências externas são praticadas" (SOLIGO, 2010, p. 125). Após análise dos objetivos e dos conteúdos de Língua Portuguesa e Matemática, propostos para o BIA no Currículo em Movimento para a Educação Básica da SEEDF, é possível afirmar que o documento dialoga com a matriz de referência da ANA, ou seja, as habilidades descritas na ANA encontram-se também descritas no currículo analisado. Com efeito, a ANA é parte de um todo mais amplo e, por isso sua análise e interpretação tornam-se necessárias.

Conclui-se que o simples fato de serem criados e desenvolvidos espaços de reflexão por meio de formações nas coordenações pedagógicas, reuniões sistemáticas, conselhos de classe e até mesmo grupos de trabalho "podem ser o caminho mais eficiente para a melhoria das práticas pedagógicas e da significação dos processos e resultados das avaliações, tanto internas como externas" (SOLIGO, 2010, p. 131). Do contrário, toda e qualquer avaliação servirá tão somente à lógica excludente e classificatória de estudantes, professores e escolas.

\section{LOCUS E SUJEITOS DA PESQUISA}

A Escola Classe, locus da pesquisa, situa-se no Distrito Federal (DF) e será aqui denominada como Escola Classe A (EC A). Ela atende estudantes do $1^{\circ}$ ao $5^{\circ}$ ano do Ensino 
Fundamental Anos Iniciais com faixa etária entre seis e treze anos de idade. Ao todo, em 2018 eram 427 estudantes matriculados e distribuídos do $1^{\circ}$ ao $5^{\circ}$ ano e uma Classe Especial.

A complexidade da gestão é de nível 3 (três), isso quer dizer que, a Escola Classe A tem, em geral, entre 50 e 500 matrículas, funciona dois turnos, com oferta de duas ou três etapas de ensino (CENSO, 2017).

A EC A implantou o BIA em 2006 e, somente a partir de 2014, aderiu a ampliação da proposta do $2^{\circ}$ Ciclo para as Aprendizagens procedendo com a implantação do $2^{\circ} \mathrm{Bloco}, 4^{\circ}$ e $5^{\circ}$ anos do EF - Anos Iniciais.

\section{ANÁLISE E DISCUSS Ão DOS DADOS EMPÍRICOS}

\subsection{Dados coletados por meio de questionário}

Nos dias 7 e 14/11/18 foi aplicado questionário com os 10 (dez) professores do BIA. Junto ao questionário foi apresentado o Termo de Consentimento Livre e Esclarecido, contendo os objetivos da pesquisa e a garantia do sigilo das informações prestadas. Com a aplicação do questionário, objetivou-se compreender como a ANA vem sendo percebida pelos professores do BIA.

Para manter o sigilo dos respondentes, as respostas da questão aberta foram transcritas empregando a seguinte identificação: P seguido de um número de 1 a 10 (P1, P2...). É válido destacar que todas as professoras, respondentes, atuam nas etapas $\left(1^{\circ}, 2^{\circ}\right.$ e $3^{\circ}$ ano $)$ do Bloco Inicial de Alfabetização.

Quadro 1 - Perfil das professoras que responderam ao questionário.

\begin{tabular}{|l|l|l|}
\hline Professor & Formação Inicial & Tempo de magistério \\
\hline P1 & Pedagoga & Entre 11 e 20 anos \\
\hline P2 & Pedagoga & Acima de 20 anos \\
\hline P3 & Pedagoga & Acima de 20 anos \\
\hline P4 & Pedagoga & Até 5 anos \\
\hline P5 & Pedagoga & Entre 6 e 10 anos \\
\hline P6 & Pedagoga & Entre 11 e 20 anos \\
\hline P7 & Pedagoga & Até 5 anos \\
\hline P8 & Pedagoga & Entre 11 e 20 anos \\
\hline P9 & Pedagoga & Abaixo de 5 anos \\
\hline P10 & Pedagoga & Até 5 anos \\
\hline
\end{tabular}

Fonte: elaborado pelos autores.

O questionário continha 8 (oito) questões afirmativas, fechadas e uma questão demográfica contemplando as seguintes informações: idade; gênero; formação; formação continuada; situação funcional; tempo de magistério e tempo de experiência com alfabetização.

Para as questões fechadas, foi empregada uma temática central, que conduziu às questões afirmativas: Sobre a ANA subsidiar nos processos pedagógicos assinale o seu nível de concordância. As respostas foram associadas a uma escala Likert crescente de concordância 
dos números de 1 (um) a 5 (cinco) variando entre: (1) discordo totalmente; (2) discordo um pouco; (3) nem discordo nem concordo; (4) concordo um pouco e, (5) concordo totalmente.

Foi avaliado o nível de concordância dos professores do BIA quanto ao uso dos resultados da ANA nas seguintes situações: (1) no Plano de Ensino; (2) no processo avaliativo (3) no processo de ensino-aprendizagem; (4) na coordenação pedagógica; (5) no processo interventivo; (6) na comunicação com a família (7) na formação continuada docente; (8) na prática pedagógica.

O questionário foi finalizado com a seguinte questão aberta: você utiliza os resultados da ANA para redirecionar o processo de aprendizagem dos seus estudantes? Como você costuma utilizar os dados?

A segunda questão do questionário versava sobre os professores conhecerem a política, suas finalidades e haver participado da aplicação em anos anteriores: 8(oito) professoras informaram que sabem o que é a ANA, e somente 2 (duas) professoras afirmaram desconhecer e expressaram da seguinte maneira:

\footnotetext{
No momento não tive nenhuma informação sobre a ANA (P9);

Estou em experiência, é minha primeira regência no $2^{\circ}$ ano do Fundamental, e por isso não conheço a ANA (P7).
}

Quando questionadas sobre saberem para que serve esta avaliação: 5 (cinco) responderam saber e, 5 (cinco) professoras negaram conhecer as finalidades dessa política. Dessa forma, mesmo aquelas professoras que tenham sinalizado ter conhecimento do que seja a ANA desconhecem para que ela serve. A falta de clareza ou o desconhecimento das finalidades da política sugere que as estratégias de implementação, na EC A tenham ocorrido de forma verticalizada (de cima para baixo) sem que houvesse a participação dos profissionais que atuam nela. Tal ação negligencia a participação daqueles que exercem papel ativo no processo de interpretação e reinterpretação da política (MAINARDES, 2007).

Quanto à participação na aplicação da ANA em anos anteriores: 5 (cinco) professoras afirmaram ter participado, e as outras 5(cinco), embora, tenham tempo de experiência em classes de alfabetização, afirmaram não ter participado de aplicações da ANA em 2013, 2014 ou 2016. Na SEEDF é definido por meio de Portaria os critérios do processo para escolha de turma a cada ano letivo. Nesse sentido, não é garantido a permanência do professor, ao longo dos anos de trabalho, em classes de alfabetização. Essa rotatividade faz com que mesmo tendo atuado em classe de alfabetização o docente não tenha participado da aplicação da ANA, por lecionar nos $1^{\text {os }}$ ou $2^{\text {os }}$ anos do $2^{\circ}$ ciclo.

Uma das professoras que participou em anos anteriores da aplicação da ANA relatou que: chegam com os malotes e aplicam. Ficamos em sala, mas não podemos interferir em nada. Então, a gente fica meio por fora (P2). Outra professora relatou que: neste ano ainda não foi conversado nada sobre a ANA (P9). A P2 é efetiva na EC A e atuou nos últimos cinco anos com classes de alfabetização, ou seja, poderia ter conhecimento acerca da ANA e dos seus objetivos, mas por algum motivo isso não ocorreu até o presente momento, novembro de 2018. A expressão "chegam" refere-se às pessoas externas a escola, mas que também não participam da formulação da política apenas da logística de aplicação. 
A terceira questão, perguntava sobre os resultados da ANA subsidiar os processos pedagógicos desenvolvidos em sala de aula e na escola. Foram descritas 9 (nove) afirmativas para as professoras assinalarem de 1 (um) a 5 (cinco), entre discordo totalmente e concordo totalmente. Do total de 10 (dez) respondentes, 9 (nove) professoras responderam às questões e, 1 (uma) devolveu em branco. As questões foram sendo lidas e discutidas com o grupo tendo a pesquisadora como mediadora.

Com base nas respostas das 9 (nove) professoras que assinalaram as frases afirmativas, os resultados foram descritos nos gráficos a seguir:

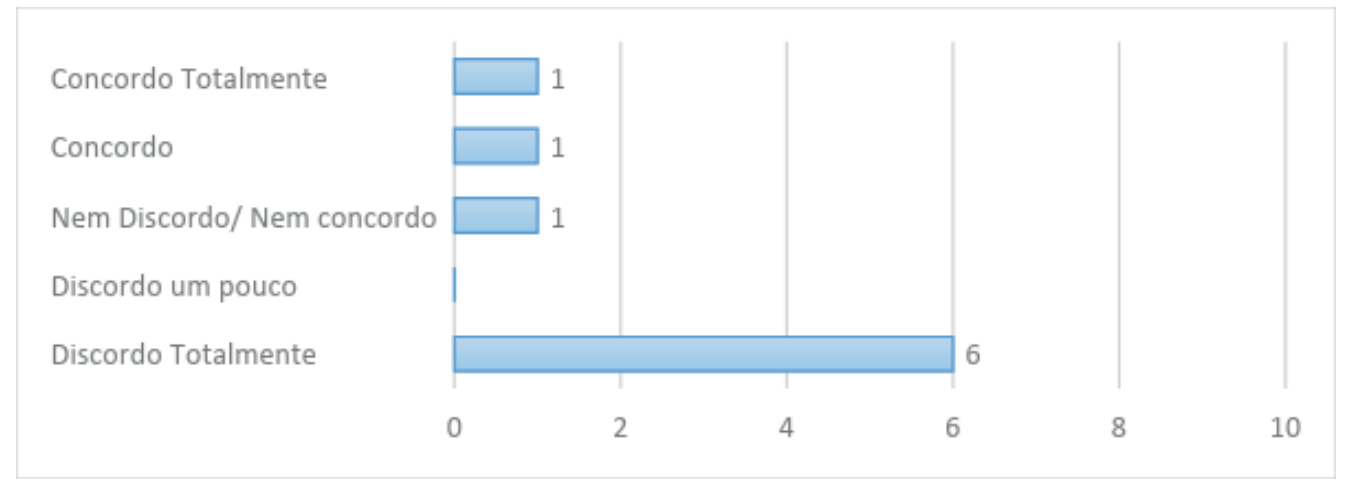

Gráfico 2 - Uso a Matriz de Referência da ANA no plano de ensino.

Fonte: dos dados originais da pesquisa.

Nessa questão, 6 (seis) professoras, mais da metade das respondentes, afirmaram discordar totalmente do uso da Matriz de Referência da ANA para o planejamento das atividades ou do uso dela para elaboração de atividades de preparação dos estudantes para realização da avaliação externa; 2 (duas) concordaram total ou parcialmente que utilizam a Matriz de Referência da ANA para nortear o trabalho pedagógico; 1 (uma) não concorda nem discorda e relatou ter pouco conhecimento das habilidades exigidas e, por isso não fazer uso da Matriz de Referência da ANA em sala de aula.

Cabe ressaltar, que conforme Documento Básico da ANA (BRASIL, 2013b), a Matriz de Referência da ANA é um recorte do conjunto de habilidades do Currículo. Assim, embora as professoras não recorram a Matriz de Referência da ANA, possivelmente estejam contemplando as habilidades exigidas ao desenvolverem suas práticas baseadas no Currículo em Movimento da SEEDF para o $1^{\circ}$ Bloco do $2^{\circ}$ ciclo.

Sobre esta possibilidade, Soligo (2010, p. 127) assevera que "mesmo que os exames contribuam para o direcionamento de saberes a serem trabalhados, o professor pode exercer sua reflexão sobre os benefícios e prejuízos de tais saberes na vida de seus estudantes". Nesse sentido, admite-se a influência da ANA no currículo praticado pela escola; porém sabe-se que o professor está envolto em um contexto mais amplo que também incidem sobre as suas escolhas (SOLIGO, 2010).

Em relação à aplicação de atividades preparatórias para a ANA, 5 (cinco) professoras discordam que tenham feito algum tipo de simulado ou teste similar com questões semelhantes às cobradas nos testes da ANA. E 1 (uma) professora relatou não ter feito testes preparató- 
rios, mas haver utilizado questões da ANA como exercício em sala apenas para os estudantes adquirirem familiaridade com questões de múltipla escolha. As demais 3 (três) professoras concordaram total ou parcialmente que tenham feito uso deste tipo de recurso didático.

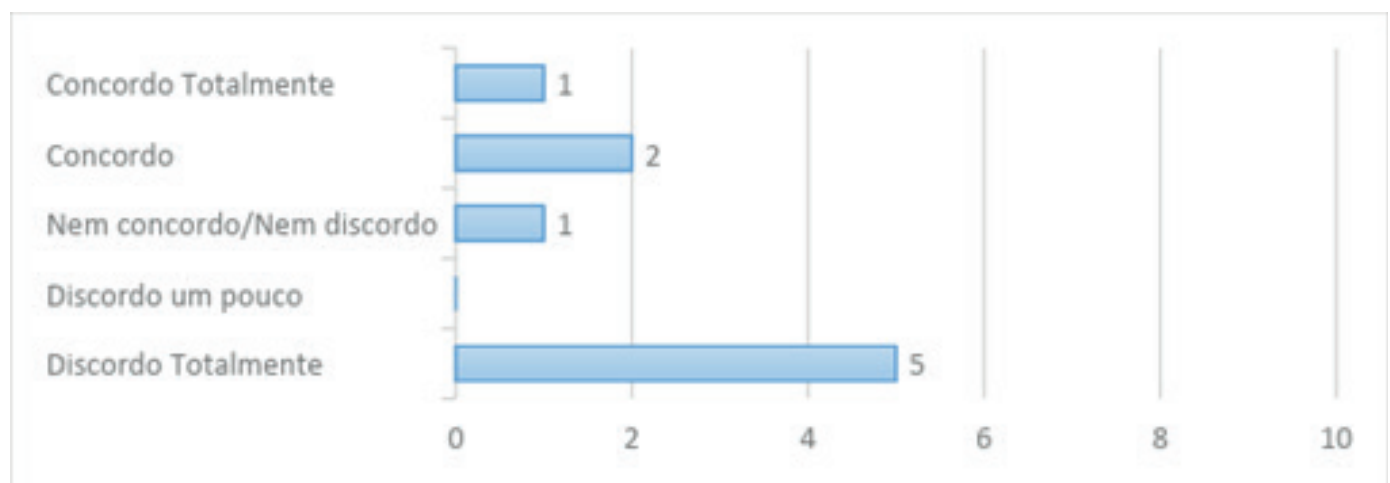

Gráfico SEQ gráfico $\downarrow^{*}$ ARABIC 3 - Aplico atividades preparatórias para a ANA.

Fonte: dos dados originais da pesquisa.

Uma das respondentes fez o seguinte esclarecimento: "poucas vezes foi realizado atividade de acordo com o modelo da prova da ANA" (P6). Tal afirmativa, sugere que nem todos os professores aderem acriticamente às avaliações externas (SILVA, 2018). Esta professora sabe o que é a ANA e participou de sua aplicação em 2016; porém afirmou desconhecer para que serve e que, por esse motivo não sabe como explorar o boletim da ANA que foi entregue este ano para os professores do BIA como meio de redirecionar o processo de ensino e aprendizagem (BRASIL, 2013b).

É pertinente destacar que este contato com os testes da ANA, a análise e discussão acerca de como são estruturados permite ao professor perceber as potencialidades das avaliações externas e sua dimensão política (SOLIGO, 2010). Dessa experiência resulta-se um processo de autoavaliação mais aprofundada e crítica acerca dos exames externos e internos, conforme evidenciado na pesquisa de Mendes, Caramelo, Arelaro, et. al. (2015) intitulada, Autoavaliação como estratégia de resistência à avaliação externa ranqueadora, envolvendo vinte escolas, treze no Brasil, sete em Porto, Portugal.

Quanto a realização de estudos e análises dos resultados da ANA para definição de estratégias e ações interventivas:

Concordo Totalmente
Concordo
Nem discordo/ Nem concord
Discordo um pouco
Discordo Totalmente
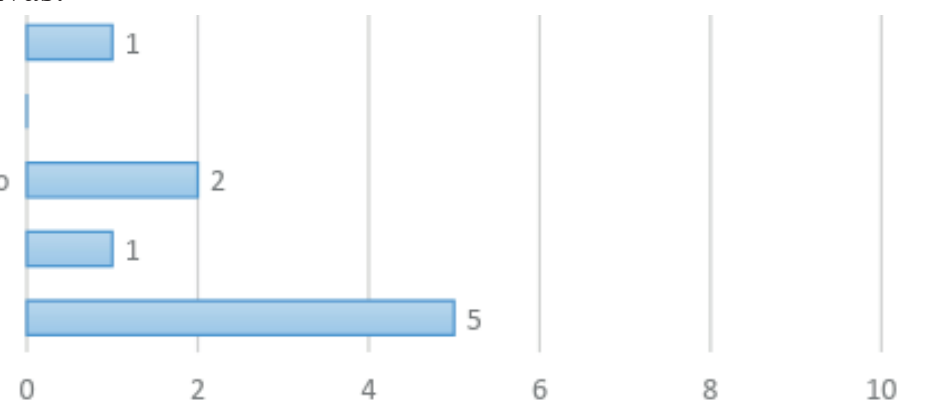

Gráfico 4 - Realizo estudos e análises dos resultados da ANA.

Fonte: dos dados originais da pesquisa. 
Nessa questão, 6 (seis) professoras discordaram total ou parcialmente que tenham realizado algum tipo de monitoramento dos resultados da ANA; 2 (duas) não concordaram nem discordaram; e apenas 1 (uma) concordou totalmente que tenha sido feito análise dos resultados; porém esclareceu que foi feito individualmente por cada professora quando a equipe diretiva entregou a cópia do Boletim da ANA/2016. Ela afirmou que "cada professor analisou os resultados, individualmente, sem que fosse ouvida a opinião de cada um" (P6).

Para esclarecer melhor esta questão conversou-se com as professoras sobre ter sido estabelecida alguma meta no PPP de curto, médio ou longo prazo objetivando superar os resultados obtidos no Boletim da ANA 2016. O PPP "é um documento que determina a organização das ações da própria escola, da direção, dos professores, dos funcionários, dos estudantes, buscando alcançar metas e objetivos educacionais bem definidos" (ALBERTON, 2017, p. 100). Ao todo, 6 (seis) professoras negaram haver participado de reuniões para elaborar ações para o PPP com base nos resultados da ANA; as demais professoras, 3 (três), informaram que consta no PPP estratégias de melhoria da qualidade de ensino do BIA, principalmente em relação à retenção, mas não sabiam afirmar se foram pensadas a partir dos resultados da ANA.

No momento não tive nenhuma informação sobre a ANA (P9); Não tenho conhecimento dos resultados desta avaliação, portanto fica difícil trabalhar em cima dos mesmos (P2); É o primeiro ano que trabalho aqui e quando cheguei já havia sido aplicada a ANA (P10). Não conheço a ANA e espero e quero aprender muito em breve (P7).

O que se verifica com os relatos das professoras é que a educação escolar da EC A ainda não se encontra subordinada exclusivamente a resultados no qual são postas metas e os professores devem se virar para atingi-las (LIBÂNEO, 2004). Entende-se que "a percepção do trabalho docente como uma atividade voltada para resultados retira algumas características essenciais do trabalho docente e de sua identidade profissional" (SILVA, 2018, p. 136).

Em relação à socialização e discussão dos resultados da ANA com as famílias dos estudantes, obteve-se as seguintes respostas:

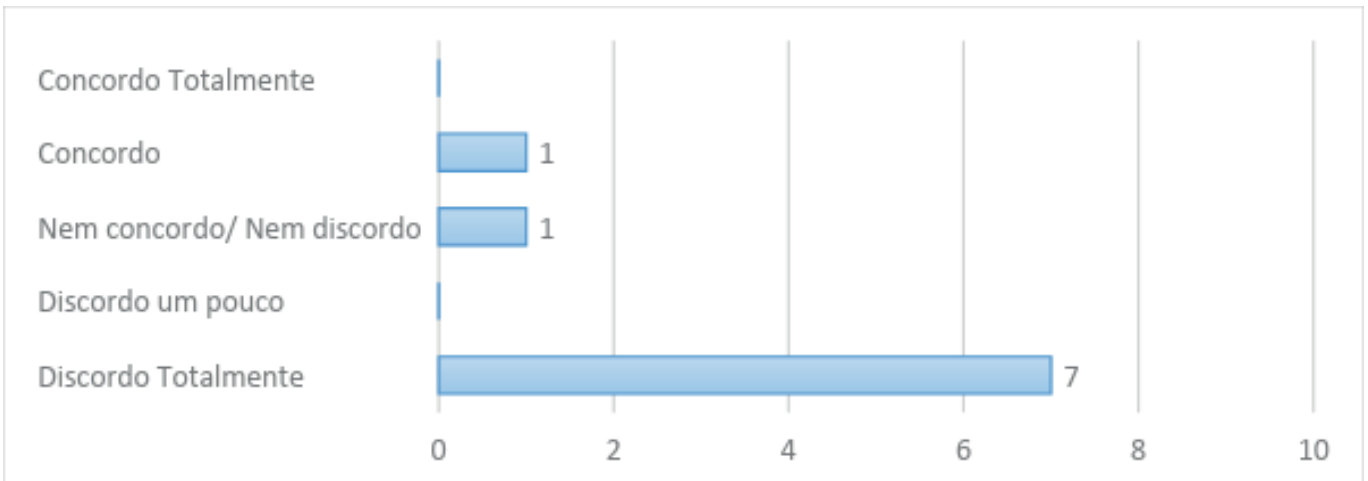

Gráfico 5 - Socializo e discuto os resultados da ANA com os pais dos estudantes.

Fonte: dos dados originais da pesquisa. 
A prática de socialização dos resultados com os pais dos estudantes representa a possibilidade de inserção deles no diálogo sobre a realidade escolar permitindo a criação de um processo de conhecimento do trabalho conjunto e agregação de vontades compartilhadas para promover a melhoria contínua da escola, conforme apontado por Lück (2012). O gráfico demonstra que, na EC A, os resultados da ANA ainda não são amplamente divulgados e discutidos com as famílias dos estudantes do BIA. Segundo Soligo (2010, p. 129), "a interação entre família e escola pode ser um dos caminhos importantes para a reflexão mais ampliada sobre os resultados das avaliações". Cabe ressaltar que as Diretrizes de Avaliação (SEEDF, 2014a) enfatizam a necessidade de envolver a família no processo avaliativo como prática de uma gestão democrática.

Quanto à importância da ANA para identificação dos problemas de aprendizagem dos estudantes do BIA os dados coletados foram expressos no gráfico 11.

\section{Concordo Totalmente}

Concordo

Nem concordo/Nem discordo

Discordo um pouco

Discordo Totalmente

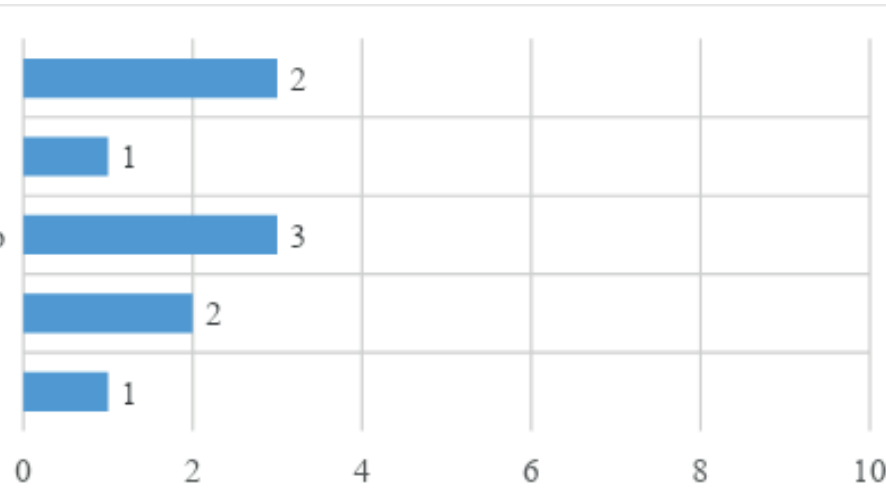

Gráfico 6 - Considero a ANA importante para identificação dos problemas de aprendizagem dos meus estudantes.

Fonte: dos dados originais da pesquisa

Das respondentes, 3 (três) professoras consideraram a política importante para este fim. E outras 3 (três) professoras discordaram total ou parcialmente da relevância da ANA para identificação dos problemas de aprendizagem dos estudantes do BIA. Elas relataram que na EC A é aplicado bimestralmente o teste da psicogênese, e que ele é mais eficaz quanto ao diagnóstico do nível de aprendizagem e na identificação das possíveis dificuldades dos estudantes do que a ANA.

As 3 (três) professoras que consideraram a ANA relevante esclareceram que por se tratar de uma avaliação externa acaba trazendo informações que passam desapercebidas nas avaliações de sala de aula, mas alegaram que a ANA é pouco discutida e explorada e, por isso torna-se dispensável. Teve ainda 3(três) professoras que consideram a ANA importante; porém desconhecem suas finalidades e o uso de seus resultados no BIA e, por esse motivo não concordaram nem discordaram com a afirmativa de que a ANA seja importante na identificação dos problemas de aprendizagem dos estudantes.

Segundo Libâneo (2018, p. 69), "os resultados de desempenho escolar dos estudantes podem servir para o controle do trabalho das escolas e dos professores, mas não ajudam a tomar medidas como ajudar os estudantes a aprender melhor, como melhor o ambiente para melhorar a aprendizagem (...)". 
Um dos objetivos da ANA é avaliar para redirecionar o processo de ensino-aprendizagem em sala de aula. Quanto à ANA subsidiar o trabalho docente em sala de aula os professores da EC A responderam que:

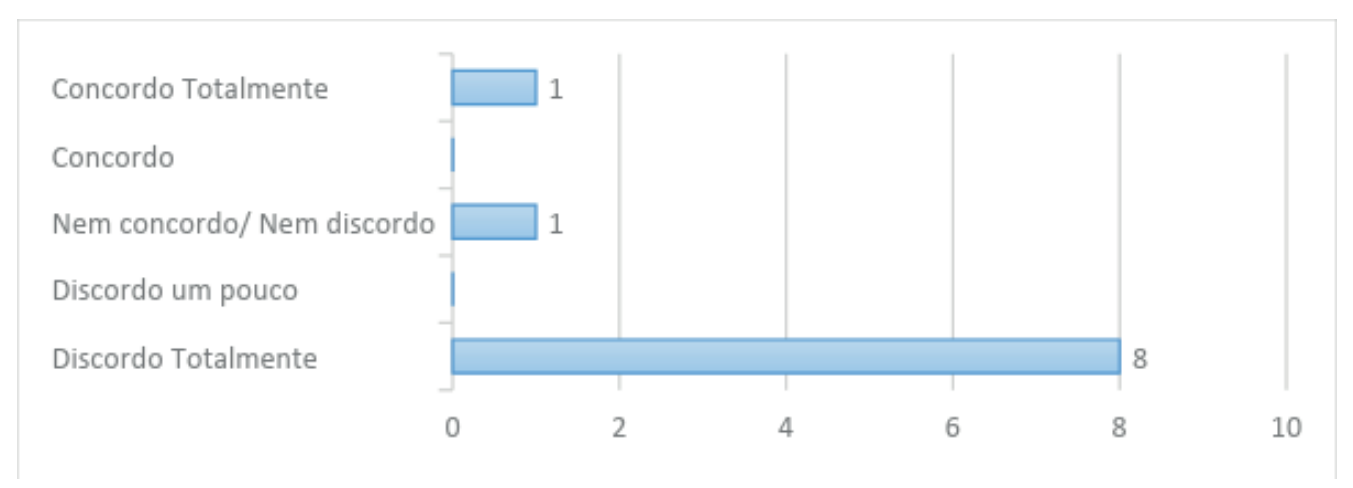

Gráfico 7 - A ANA tem subsidiado meu trabalho em sala de aula.

Fonte: dos dados originais da pesquisa

Do total de respondentes, apenas 2 (duas) professoras concordam total ou parcialmente que a ANA tem subsidiado o trabalho em sala de aula, e esclareceram o motivo pelo qual concordam com esta afirmativa.

Acredito que a ANA é mais um instrumento que auxilia o professor em seu processo de ensino-aprendizagem, à medida que, possibilita identificar estudantes que necessitam de acompanhamento para progredir em sua aprendizagem (P1); A ANA tem auxiliado a minha prática, dando direção, tirando dúvidas, mostrando caminhos e recursos a serem utilizados (P4);

As outras professoras, 8 (oito) discordaram totalmente desta afirmativa e, durante a conversa com a pesquisadora fizeram os seguintes relatos:

O currículo, os projetos pedagógicos, o PPP, que tem subsidiado minha prática pedagógica ( $\mathrm{P} 2)$; $\mathrm{O}$ trabalho na escola tem se orientado mais pelos próprios projetos previstos no PPP (P3); A escola trabalha em cima do currículo (P6); Acompanhei os resultados dos alunos e sei que não apresenta equivalência entre a avaliação e a realidade (P10).

Percebe-se a ausência da prática da avaliação de processo e de resultados que conforme apontado por Ramos e Schabbach (2012) garante a identificação de possíveis problemas ao longo do processo de implementação de uma política permitindo a realização de ajuste ou correções, se necessário. Além disso, fica evidenciado a inexistência da avaliação dos resultados, ou seja, a verificação se de fato a ANA alcançou os seus objetivos propostos e quais os principais resultados obtidos a partir da implementação desta política.

Pode-se inferir que a ANA é uma política ainda pouco conhecida e explorada pelos professores. Seu objetivo de oferecer às escolas informações acerca da qualidade de oferta dos ciclos é parcialmente atingido tendo em vista que os resultados divulgados chegam à 
escola, no entanto, não têm subsidiado uma mudança na prática docente com vistas à melhoria do processo de alfabetização. Isso não quer dizer que na escola pesquisada inexistam processos de intervenção, ações e estratégias voltadas à aprendizagem contínua dos estudantes; porém estes estão desvinculados da ANA.

Quanto aos questionamentos que guiaram a pesquisa sobre a ANA, inserir-se no BIA numa perspectiva de avaliar para redirecionar o processo de ensino-aprendizagem em sala de aula; é possível afirmar que a escola pesquisada desenvolveu seu próprio sistema avaliativo, os testes da Psicogênese, aplicados bimestralmente. Cabe ressaltar que os resultados do Boletim da ANA quando comparados com os gráficos gerados a partir dos testes da Psicogênese, nota-se diferenças quanto à distribuição dos estudantes nos níveis de proficiência, ou seja, os dois sistemas avaliativos (interno e externo) divergem quanto à forma de avaliar o processo de alfabetização, mas convergem quanto ao objetivo de identificar lacunas do processo para fazer as crianças progredirem nas aprendizagens.

No que tange a ANA estimular a melhoria do processo de alfabetização, nota-se com base nas respostas das professoras que a política é inexpressiva, e que o currículo em movimento da SEEDF é o principal norteador de suas práticas. Na conversa com as professoras foi possível perceber que na concepção delas, a ANA é uma avaliação externa que: cai de paraquedas na sala de aula, é descontextualizada, e, que, portanto, torna-se sem sentido tanto para os professores quanto para os alunos (P2, P3, P5, P6, P7, P8, P9 e P10). As professoras relataram que os seus resultados são apreciados de forma superficial, individualmente, sem que haja uma sistematização de ações e estratégias voltadas à melhoria da aprendizagem dos estudantes do BIA (P2, P3, P5, P6, P7, P8, P9 e P10). Dessa forma, fica a cargo de cada professor decidir se deve ou não realizar análise dos resultados do Boletim da ANA e utilizá-los. Percebe-se, nesse sentido, que os resultados desta avaliação externa não vêm sendo utilizados para produzir ajustes nas práticas pedagógicas dos professores do BIA com vistas a obtenção de melhores resultados nas próximas avaliações (FREITAS; LIBÂNEO; SILVA, 2018). Os dados mostram também que nesta escola não ocorre a inter-relação entre a política, a organização escolar e as práticas pedagógicas na sala de aula

Conclui-se que, embora as professoras percebam a relevância desta política, saibam o que é, desconhecem suas finalidades e, por isso não a utilizam em sua prática docente, ou seja, a aplicação da ANA é reduzida a um mero cumprimento de uma exigência legal determinada pelo MEC. Essa mesma expressão cai de paraquedas também foi identificada na entrevista com a gestora, ao relatar que: a ANA é esse instrumento que cai de paraquedas né[sic] e que não tem nada a ver com o que está sendo dito na escola. E isso não é bom. A gente entende que está cumprindo uma obrigação. Não descartando a importância também, entende?! Ela vira um trabalho a mais.

Os demais dados coletados por meio da entrevista estão descritos no item a seguir e refletem, na percepção da equipe diretiva da escola, de como a ANA é percebida pelos professores e quais as ações que são desenvolvidas na EC A para materialização da política.

\subsection{Dados coletados por meio de entrevista semiestruturada}

Para a escolha do (a) entrevistado (a), foram definidos os seguintes critérios: 1) ser membro da equipe diretiva; 2) ter participado de reuniões sobre a ANA ofertadas pelos ór- 
gãos reguladores; 3) ter conhecimento, ou seja, responsável pela condução do processo de implementação da ANA na escola.

Com a prática da entrevista, buscou-se obter informações sobre como a ANA é percebida pelos professores e identificar as ações que são desenvolvidas pela equipe gestora para materialização da política. Os textos, transcritos da entrevista, foram fragmentados em unidades de análise. Ao todo, foram extraídas 41 (quarenta e uma) unidades base.

As categorias foram definidas, a priori, baseadas nos operadores cognitivos do pensamento complexo (MARIOTTI, 2007). Cada unidade de análise foi associada a uma ou mais das categorias preestabelecidas. O quadro, a seguir, contempla a relação estabelecida entre as questões da entrevista semiestruturada e os Operadores Cognitivos do Pensamento Complexo (MARIOTTI, 2007).

Quadro 2 - Relação entre os Operadores Cognitivos do Pensamento Complexo e as questões da entrevista semiestruturada.

\begin{tabular}{|l|c|}
\hline $\begin{array}{l}\text { Operadores cognitivos do Pen- } \\
\text { samento complexo }\end{array}$ & Questões da Entrevista \\
\hline Circularidade & $\begin{array}{r}\text { Descreva as ações desenvolvidas na Escola após divulgação } \\
\text { dos resultados da ANA? Como a Escola (equipe diretiva, } \\
\text { coordenaça e professores) organiza os estudos e as análises } \\
\text { dos resultados da ANA? }\end{array}$ \\
\hline Autoprodução & $\begin{array}{r}\text { Em sua opinião, ocorreram mudanças na prática pedagógica } \\
\text { dos professores após a implantação da ANA? } \\
\text { Comente sobre isso. }\end{array}$ \\
\hline Operador Dialógico & $\begin{array}{r}\text { Em sua opinião, foram identificadas dificuldades para efetiva- } \\
\text { ção da ANA em sua escola? Você poderia descrevê-las? }\end{array}$ \\
\hline Operador Hologramático & $\begin{array}{c}\text { Comente o que você sabe sobre a ANA. } \\
\text { Descreva qual a importância da ANA para } \\
\text { você e seus estudantes. }\end{array}$ \\
\hline Interação sujeito-objeto & $\begin{array}{r}\text { Como a ANA é percebida na sua Escola? Você notou } \\
\text { resistência? Aceitação? Valorização? }\end{array}$ \\
\hline Ecologia da Ação & $\begin{array}{c}\text { A escola recebe ou recebeu algum tipo de assessoria externa } \\
\text { sobre como proceder com a implementação da ANA? Você } \\
\text { poderia detalhar como foi feita esta assessoria? }\end{array}$ \\
\hline
\end{tabular}

Fonte: elaborado pelos autores (2019).

\subsection{Comunicação das compreensões emergentes}

\subsubsection{Circularidade}

A primeira categoria analisada é a circularidade ou recursividade, operador fundamental do pensamento complexo, que se apoia no feedback enquanto recurso de manutenção do equilíbrio de um sistema diante das variações do meio (MARIOTTI, 2007). De acordo com Mariotti (2007, p. 141), "a troca de informações e o intercâmbio de ideias define e estabiliza os comportamentos, e com ele o clima grupal". 
No contexto escolar da SEEDF, toda e qualquer ação empreendida na escola, é ou pelo menos deveria ser discutida na coordenação pedagógica. O horário de coordenação, inserido na jornada de trabalho dos professores da SEEDF, por seu caráter coletivo, possibilita espaços de reflexão e debates acerca de questões relativas ao contexto escolar. A coordenação pedagógica, na SEEDF, destina-se à "realização de reuniões pedagógicas e administrativas, planejamentos, preparação de materiais pedagógicos, estudos coletivos, reforço para aluno, conselho de classe e outras atividades, representando um avanço no sistema de ensino do Distrito Federal (FERNANDES, 2010, p.96). Nesse sentido, é possível afirmar que a coordenação pedagógica viabiliza a troca de informações, a formação continuada e o intercâmbio de ideias entre o colegiado. Segundo Fernandes (2010, p. 89) cabe aos docentes e gestores "assegurarem esse espaço e tempo nessa perspectiva porque, como uma construção coletiva, é uma conquista do grupo".

Para análise desta categoria, foram elaboradas questões destinadas a colher informações sobre a percepção da gestora acerca da política apoiar-se no feedback enquanto recurso de manutenção da unidade do sistema. Assim foram feitos os seguintes questionamentos: Descreva as ações que são desenvolvidas na Escola após divulgação dos resultados da ANA. Como a Escola (equipe diretiva, coordenação e professores) organiza os estudos e as análises dos resultados da ANA.

Foi relatado pela gestora que não houve reuniões com tal finalidade: não foi feito $o$ ano passado, 2017, esse estudo com vistas a gerar uma nova prática pedagógica. (...) Não foi feito trabalho nenhum. Quando chegou na escola o Boletim, eu estava em sala de aula. Recebi o resultado da minha turma, observei aquilo que eu precisava desenvolver melhor, individualmente. A gestora afirmou também não ter havido divulgação dos resultados para os responsáveis pelos estudantes.

A ausência do intercâmbio das informações sobre os resultados da ANA sugere que a intercomplementaridade entre a gestão educacional e a gestão escolar mostra-se fragilizada (MACHADO, 2017). Compreende-se que uma política pública educacional, embora, seja produzida/elaborada no âmbito da gestão educacional (macro) necessita que em seu plano de materialização (micro) sejam planejadas ações e estratégias de interpretação da política afim de que ela, de fato, venha a concretizar-se em sua inteireza.

Outro aspecto destacado pela gestora é a não divulgação dos resultados da ANA para os pais dos estudantes. A propósito disso, Paro (2017), esclarece que a operacionalização de uma política, por meio de uma gestão democrática ainda é desafiadora em boa parte das escolas públicas. Mainardes (2007) argumenta que a construção e operacionalização de uma política seria mais benéfica se houvesse uma partilha maior com aqueles que participam e trabalham nas unidades escolares.

O relato da gestora sobre não ter sido discutido e divulgado os resultados da ANA guarda estreita relação com as respostas dadas pelas professoras no questionário. As 10 (dez) professoras respondentes do questionário informaram que os resultados da ANA não foram divulgados e discutidos com as famílias dos estudantes do BIA. Essa constatação, reafirma a percepção de Vieira (2009) sobre no Brasil os indicadores para mensurar aspectos relacionados ao processo educativo, como o desempenho dos estudantes e o rendimento escolar, nem sempre serem explorados e aproveitados em sua plenitude, tendo em vista 
que, poucos gestores públicos valorizam as informações que podem ser extraídas das avaliações externas.

Sem a intenção de discutir quanto à assertividade da decisão feita pela gestão escolar em não divulgar os resultados da ANA, é preciso evocar aqui a teoria dos sistemas abertos para explicitar que a escola enquanto sistema aberto (MORIN, 2011) se não quiser estagnar, deve abrir-se à comunidade e com ela dialogar, pois parafraseando Alarcão (2001, p. 27) "se quisermos mudar a escola, devemos assumi-la como organismo vivo, dinâmico, capaz de atuar em situação, de interagir e desenvolver-se ecologicamente sobre si própria nesse processo".

Com base no relato, infere-se que a ANA, na realidade pesquisada, mostra-se pouco expressiva e, por isso não assume sua característica de ser utilizada como ponto de partida para realização da avaliação institucional sobre as práticas pedagógicas de alfabetização (MACHADO, 2017). Nota-se que, nesse sentido, a direção da escola tem por desafio tornar o processo avaliativo, em todos os seus níveis, um aliado para a promoção das mudanças (LIMA, 2012). Constata-se ainda que a ausência do debate, do diálogo, da busca de um consenso sobre a ANA, nesta comunidade, pode contribuir para desvalorização da política, uma vez que, sua prática torna-se um fim em si mesma, esvaziada de sentido para àqueles que a executam. Segundo Bomfim (2017, p. 65), “o sentido é uma construção coletiva, um empreendimento interativo, por meio do qual os agentes, na dinâmica das relações sociais, culturalmente localizadas, constroem os termos e, com base neles, compreendem e lidam com as situações e fenômenos".

\subsubsection{Autoprodução}

O princípio da Autoprodução vale para todos os seres vivos, seus ambientes, grupos, organizações ou instituições humanas. Segundo Mariotti (2007, p. 145), “o meio produz alterações contínuas na estrutura do sistema e estes, por sua vez, atuam sobre o meio e o modificam também de modo incessante". Assim, somos produtos e produtores numa relação de autonomia-dependência (MARIOTTI, 2007). Com esta categoria, buscou-se identificar a reciprocidade autonomia/dependência da escola em relação à avaliação externa.

A ANA foi instituída no contexto do BIA com a função de fornecer informações que subsidiem a mudança da prática pedagógica (BRASIL, 2013b). Os boletins gerados pela ANA trazem informações detalhadas acerca do desempenho dos educandos permitindo que a escola busque em sua análise identificar potencialidades e fragilidades do processo de alfabetização. Importava, nesse sentido, identificar tendo como lente teórica o princípio da Autoprodução de Mariotti (2007) da relação de autonomia-dependência entre a ANA e a prática pedagógica partindo do princípio de que a ANA não apenas avalia as condições de oferta do BIA, mas também possibilita a autoavaliação como uma estratégia de melhoria contínua.

Sobre uma possível mudança na prática pedagógica após a implantação da ANA, a gestora esclareceu que: a gente[sic] tem uns cinco anos de ANA e no início houve muita resistência muita...muita...muita [sic]. Foi assim muito difícil para os professores aceitarem essa avaliação. Houve muitas críticas, mas com o tempo o professor passou a se preocupar com isso porque isso[sic] entra no ranking nacional. 
Nota-se que há uma preocupação por parte da gestora quanto a divulgação dos resultados na forma de ranking. Este relato confirma a concepção de que a qualidade do ensino vem sendo referenciada aos resultados obtidos pelos estudantes nas avaliações externas (OLIVEIRA; ARAÚJO, 2005; OVANDO; FREITAS, 2011; VIEIRA, 2009; LIBÂNEO, 2004; CASASSUS, 1997; HORTA NETO 2010; FERREIRA; OLIVEIRA, 2013). Cabe ressaltar que no Documento Básico da ANA (BRASIL, 2013b), os resultados desta avaliação externa não são divulgados neste formato. O Inep emite boletins das escolas sem que haja divulgação dos resultados por aluno ou por turma. Também são divulgados resultados por região, estados e municípios, mas sem discriminar as escolas, individualmente, na forma de ranqueamento.

O principal objetivo da ANA é oferecer um panorama geral da escola para que seja monitorado a concentração dos estudantes, conforme os níveis de proficiência (BRASIL, 2013b). Assim, um percentual de estudantes concentrados em níveis de proficiência considerados insuficientes necessita ser analisado e discutido pela equipe pedagógica da escola e professores buscando identificar lacunas do processo educativo geradoras de tal resultado a fim de que possam ser sanados possíveis problemas e corrigido rumos.

É sempre motivo de preocupação a ideia de nortear o trabalho a partir daquilo que será cobrado numa avaliação externa, pois remete a uma ideia de racionalização do ensino (GENTILI, s/d) na qual é negligenciado o exercício da prática docente reflexiva (GIROUX, 1990). Por outro lado, conforme apontado por Freitas et. al. (2009), em virtude da interface que vem sendo estabelecida entre a avaliação e as políticas públicas educacionais nas últimas décadas é importante que as escolas aceitem como parte integrante de sua prática a avaliação em seus três níveis. Dessa forma, ao invés de tentar contradizer, afastar, esquecer, colocar de lado se prendendo a um sistema coerente (MORIN, 2011), é mais interessante que a escola busque criar estruturas onde sejam intensificadas as interações entre a ANA e a prática pedagógica da escola, a fim de potencializar processos adaptativos geradores de mudança.

\subsubsection{Operador Dialógico}

Esta categoria diz que "há contradições que não podem ser resolvidas. Isso significa que existem opostos que são ao mesmo tempo antagônicos e complementares" (MORATTI, 2007, p. 150). Para esta categoria, foi formulada a seguinte questão: Em sua opinião, foram identificadas dificuldades para efetivação da ANA em sua escola? Você poderia descrevê-las? A análise desta categoria possibilitou identificar as divergências entre aquilo a que se propõe a ANA e a sua prática real.

Sobre as dificuldades encontradas para efetivação da ANA em sua escola, a gestora relatou que: uma das dificuldades que a gente tem com os professores dos anos iniciais é que eles trabalham, eles fazem muito, eles se dedicam muito, mas existe uma resistência a essa sistematização do planejamento. $\mathrm{O}$ operador dialógico traduz "a capacidade que têm os grupos, organizações ou instituições de buscar soluções para suas dificuldades, sem que para tanto sejam necessárias diretivas vindas de fora" (MARIOTTI, 2007, p. 151).

Embora, não haja rejeição à política, a gestora esclareceu que o principal obstáculo encontrado para o uso das informações fornecidas pela ANA é a dificuldade em articular e 
sistematizar com os professores um planejamento para este fim. Em suas palavras: Não é por incompetência ou falta de compromisso nem nada, mas falta de planejamento. A fala da professora (P7) reforça essa afirmativa quando diz que: Não conheço a ANA e espero e quero aprender muito em breve (P7). Assim, evidencia-se que a implementação da ANA, na escola pesquisada, é marcada muito mais pela ausência de um planejamento que favoreça o entendimento das implicações, princípios, finalidades e resultados desta política do que pela resistência e discordância dos professores a ela. A ANA tem sido executada como uma tarefa cujos objetivos são desconhecidos e, por isso ela torna-se sem sentido para aqueles que a cumprem.

Para o enfrentamento das divergências que emergem do processo de implementação de uma política, Mainardes (2007) aponta como aspectos essenciais o diálogo e a negociação. O autor (2007) destaca que níveis elevados de cooperação e interação entre o grupo de professores favorece a prática da política. Com isso, não significa que haverá o consenso ou que todos os aspectos da política serão acolhidos. Mas, o processo torna-se mais rico na medida em que o grupo por meio da busca de alternativas e soluções para os problemas enfrentados é naturalmente impulsionado à formação de uma consciência coletiva ${ }^{1}$.

\subsubsection{Operador Hologramático}

Esta categoria diz que "as partes estão no todo, mas o todo também está nas partes" (MARIOTTI, 2007, p. 154). Para análise foram feitos os seguintes questionamentos: Comente o que você sabe sobre a ANA. Descreva qual a importância da ANA para você e para os seus estudantes.

Sobre conhecer a política e suas finalidades a gestora respondeu que: a Avaliação Nacional da Alfabetização é uma política pública que visa avaliar mesmo[sic], medir o conhecimento em alfabetização em nível nacional com vistas a implementação de ações, de estratégias para valorizar e corrigir os déficits de alfabetização no Brasil. Ela é um instrumento de medição mesmo [sic] de conhecimento das crianças, do nível de aprendizagem das crianças em relação à alfabetização e ao letramento.

Conforme Documento Básico da ANA (BRASIL, 2013b), além de avaliar o processo de ensino-aprendizagem em sala de aula, ela, também fornece dados que servem para redirecionar, caso seja necessário, os processos pedagógicos. Além disso, é objetivo da ANA induzir a produção de políticas educacionais tendo como foco a melhoria da alfabetização no país (BRASIL, 2013b). De acordo com a fala da gestora, verifica-se que a ANA não foi percebida como uma possível orientadora do processo alfabetizador dos estudantes. Desta forma, a gestora, embora saiba o que é a ANA e suas finalidades, não assumiu o papel de articuladora da construção de uma consciência coletiva com os professores por ela coordenados acerca desta política.

Quanto à relevância da política, a gestora destacou que considera importante; porém acredita que é necessário que seja revista a utilização de um mesmo instrumento em diferentes realidades, fazendo o seguinte relato: Considero muito importante, mas por perceber

1 Conceituada por Lefebvre (1985) como a consciência coletiva, a qual não surge da espontaneidade, mas emerge na e da realidade objetiva brutal, inicialmente pela resistência, depois pelo enfrentamento e busca de alternativas, e amplia-se para toda a vida do sujeito individual e social (BRZEZINSKI, 2001, p. 70). 
a complexidade do país não só em relação à dimensão geográfica, mas a pluralidade cultural, a diferença das regiões em termos de escolaridade, de qualidade de vida. Eu acho que tudo isso influencia. Você fazer a medição do nivvel de alfabetização de uma criança no Chui e na capital do país usando o mesmo instrumento, eu acho um equivoco.

A percepção da gestora é de que a avaliação externa, no caso a ANA, não consegue atender às diferenças existentes entre os diferentes sistemas de ensino do país. Sobre esta percepção apontada pela gestora, Libâneo (2018, p. 70), afirma que "as provas em larga escala são aplicadas massivamente, um mesmo instrumento é aplicado para um grande número de estudantes, desconsiderando-se as condições individuais, sociais, culturais, a estrutura física da escola, as condições de trabalho dos professores e o ambiente de aprendizagem". Já o Documento Básico da ANA(BRASIL, 2013b) aponta não ser objetivo desta avaliação lidar com questões relativas a heterogeneidade dos grupos avaliados.

Sobre sua percepção quanto à complexidade da ANA se adequar às diferentes realidades, a gestora fez o seguinte comentário: todas as vezes que eu vi o instrumento eu achei que era falho em alguns aspectos porque eu achei que algumas questões teriam algum significado para alguns grupos e não para outros. De acordo com o Documento Básico da ANA (BRASIL, 2013b), a Matriz de Referência de Língua Portuguesa e de Matemática utilizada para elaboração dos testes contemplam habilidades da Base Nacional Comum Curricular (BNCC) do Ensino Fundamental, Anos Iniciais, que por sua vez, é a norteadora do Currículo praticado no $2^{\circ}$ Ciclo da SEEDF.

Dessa maneira, mesmo utilizando um único instrumento para avaliar realidades tão diversas, aquilo que é cobrado na ANA está alinhado à BNCC e, provavelmente, ao Currículo praticado nos estabelecimentos de ensino público do DF. Conforme apontado por Libâneo (2012), o currículo, praticado nas escolas do país, tem sua origem nas orientações de organismos internacionais. Esse processo de internacionalização das políticas educacionais, segundo Silva (2018), imprimem uma marca de padronização e uniformização da educação escolar e, por isso, não é objetivo das avaliações externas lidar com as diferentes condições individuais, sociais, físicas e culturais existentes

Nota-se, com base no relato da gestora, que os resultados dessa avaliação externa encerram-se em si mesmo: é importante, mas eu acho que está muito distante do ideal (...) Abre margem pra que essa avaliação não seja tão fidedigna, não seja justa né em termos dessa diversidade cultural. Essa mesma percepção foi constatada na pesquisa de Dias (2015) sobre outra avaliação externa, a Prova Brasil. Desse modo, infere-se que a ANA, na realidade pesquisada, ainda não adquiriu o reconhecimento de ser parte de um projeto educativo maior, sistêmico. A escola mantém-se em contato, interage, com a dimensão global (sistema de ensino) da qual faz parte; porém protege-se de uma possível estandardização neutralizadora daquilo que não dialoga com seu universo local (ALARCÃO, 2001).

\subsubsection{Interação Sujeito-objeto}

A terceira categoria analisada é a Interação Sujeito-objeto. Segundo Mariotti (2007, p. 17) "a percepção é um fenômeno que acontece na estrutura dos organismos vivos. O mundo externo é o mesmo para todos nós, mas o universo interno difere de indivíduo para indivíduo". 
Para análise desta categoria, foi questionado à gestora sobre como a ANA foi percebida pelos professores, se houve resistência, aceitação e/ou valorização. A gestora respondeu que: apesar das resistências, porque tem muita resistência, tem aqueles que falam...trabalhei a vida inteira assim vou continuar! Que é aquele professor que pega uma cartilha né[sic] e segue da primeira folha até a última. Eu acho que hoje em dia a maior parte desse grupo já se aposentou, né[sic] que começou na década de 80 com uso da cartilha, já saiu, eu também sou desta época, mas infelizmente eu não estou aposentada ainda, mas assim as minhas experiências me permitiram aprender muito nessa trajetória.

A gestora enfatizou diversas vezes que houve resistência, mas destacou ter percebido uma redução da resistência à esta política com o passar dos anos. Resulta oportuno destacar que as 10 (dez) professoras, durante a aplicação do questionário, relataram que a ANA, para elas, mostra-se irrelevante do ponto de vista pedagógico e, que os seus dados, provavelmente, servem apenas para os órgãos reguladores controlarem a qualidade do ensino de cada escola. Uma professora (P2) fez o seguinte comentário: Pra mim não ajuda em nada. $N a$ verdade, acho que serve apenas ao MEC. Não vejo como usar os dados fornecidos no Boletim (P2). Esse relato evidencia a necessidade de tornar a política mais clara aos professores, de forma que consigam perceber as potencialidades advindas da avaliação externa e, não apenas as suas limitações.

Vê-se como necessário que sejam estabelecidas relações mais cooperativas e que haja um maior investimento na participação dos professores enquanto executores das políticas (MAINARDES, 2007). Nota-se que a interação sujeito-objeto na escola é fragilizada, pois a ANA é percebida pelos professores como uma política implementada de forma impositiva, autoritária, descolada da realidade e, por isso torna-se irrelevante do ponto de vista pedagógico.

\subsubsection{Ecologia da Ação}

Esta categoria diz que: "as ações frequentemente escapam ao controle de seus atores e produzem efeitos inesperados e às vezes opostos aos esperados" (MARIOTTI, 2007, p. 161). Empregou-se esta categoria para analisar e discutir como a implementação da ANA não depende somente da intenção de seus autores, mas também das condições e intenções peculiares do ambiente onde ela ocorre.

Foi então questionado se a escola recebia algum tipo de assessoria externa sobre como proceder com a implementação da ANA. Em relação a esta questão foi descrito pela gestora que: A gente tem duas coordenadoras intermediárias da regional que vem aqui, Ângela e Keila, que dão suporte a escola. Mas, assim elas vêm...participam das reuniões(...) elas são presentes, só que em relação a ANA não houve um trabalho ainda sistemático.

Verifica-se que a ANA foi implementada sem que houvesse o acompanhamento sistemático e a atuação próxima dos órgãos reguladores responsáveis. Nesse caso, não se questiona o compromisso e interesse dos autores da política em criar condições para que sua implementação ocorra da forma como foi pensada. Todavia, é essencial reconhecer que os professores e demais profissionais da escola tornam-se executores de uma política em que saibam ao certo como proceder ou quais estratégias empreender para a implementação da política. 
A gestora relatou que é dado por parte dos órgãos reguladores maior ênfase aos resultados obtidos na ANA. Esclareceu que não foram criados espaços e tempos de escuta e discussão coletiva, entre o órgão regulador e a escola, para que se avaliasse o contexto no qual esses resultados foram gerados. A esse respeito, Mainardes (2007) destaca que, embora, a estratégia de acompanhar e monitorar sejam importantes, também é fundamental a busca pelo entendimento daquilo que precisa ser mudado na realidade avaliada para que se avance na obtenção de melhorias no sistema educacional como um todo. Para Pessoni e Libâneo (2018, p. 160), "a ênfase nos dados quantitativos se sobrepõe aos qualitativos em um claro processo de legitimar a produtividade como critério de qualidade".

Assim sendo, conclui-se que o suporte oferecido para implementação da política tem sido insuficiente. A ANA chegou à escola e ficou à mercê da instabilidade e da imprevisibilidade do ambiente, fugindo ao controle de seus autores, e por isso produzindo efeitos diferentes e até mesmo opostos aos esperados.

\section{CONSIDERaÇões Finais}

Com o estudo buscou-se tecer algumas considerações sobre como a ANA é percebida pelos professores do BIA. Para atingir este objetivo, foi aplicado um questionário com as professoras do BIA e realizada uma entrevista semiestruturada com um membro da equipe diretiva. Evitamos polarizar as análises aqui concebidas buscando um entendimento a partir da lógica da circularidade, da inclusão (MARIOTTI, 2007). Na perspectiva de que "entre as polaridades há uma tensão criativa que existe por causa das contradições, dos paradoxos, da pluralidade, enfim, das situações em que ou/ou é rudimentar para compreender o mundo real" (MARIOTTI, 2007, p. 82).

Evidenciamos com a análise dos dados que os professores, embora, considerem a ANA importante, desconhecem suas finalidades e, talvez por isso ela venha sendo pouco utilizada e tenha se mostrado inexpressiva no contexto escolar pesquisado. Percebemos com a pesquisa que a ANA não tem atingido o objetivo a que se propõe que seria o de subsidiar a prática pedagógica docente em prol da melhoria do processo de alfabetização dos estudantes. Desse modo, a aplicação da ANA acaba sendo reduzida a um mero cumprimento de uma exigência legal determinada pelo Ministério da Educação, sem valoração para mudança da prática pedagógica.

Constatamos que embora o Boletim da ANA chegue à Escola, não são previstos momentos para discussão e análise, coletiva, dos resultados. Tal fato, sugere que a ANA não venha cumprindo um de seus objetivos: proporcionar a indução de ações, propostas, projetos e a reorientação de práticas pedagógicas tendo em vista a melhoria da qualidade do ensino na alfabetização (BRASIL, 2013b). Compreendemos que a criação e o desenvolvimento de espaços de reflexão por meio de formações nas coordenações pedagógicas, reuniões sistemáticas, conselhos de classe e até mesmo grupos de trabalho podem contribuir com a promoção de novas práticas docentes e a ressignificação dos processos e resultados das avaliações, tanto internas como externas.(SOLIGO, 2010). No entanto, é válido ressaltar que o planejamento de tais atividades não depende exclusivamente da escola, mas principalmente, dos órgãos reguladores responsáveis pela implantação e implementação da política. 
Ao considerarmos o objetivo da ANA de inserir-se no BIA numa perspectiva de avaliar para redirecionar o processo de ensino-aprendizagem em sala de aula e, também de induzir a produção de políticas educacionais voltadas à melhoria da qualidade da alfabetização no país, os resultados da pesquisa indicam a existência de um distanciamento entre o objetivo a que se propõe a ANA e a sua prática real. Sem a intenção de esgotar a discussão, concluímos que a ANA vem sendo constituída em meio a: a) diferentes concepções e expectativas por parte dos professores quanto às finalidades e implicações da ANA no cotidiano da escola indicando a ausência de uma consciência coletiva acerca da política; b) desvalorização da política, uma vez que, sua prática torna-se um fim em si mesma, esvaziada de sentidos para àqueles que a executam; c) ausência de ações diferenciadas por parte da equipe diretiva e dos órgãos reguladores do sistema de ensino, no tratamento dos resultados da ANA e na oferta de formação docente com vistas a uma melhor compreensão da política; d) falta de uma maior objetividade e clareza quanto às ações e estratégias que possam ser empreendidas por meio do uso de seus resultados para promoção da melhoria do processo de alfabetização no BIA; e) uma percepção de que a política é implementada de forma impositiva, autoritária, descolada da realidade e, que por isso, é concebida por seus executores como irrelevante.

\section{REFERÊNCIAS}

ALARCÃO, I. A escola reflexiva. In: Escola reflexiva e nova racionalidade. ALARCÃO, I. (org.). Porto Alegre: Artmed, 2001.

ALBERTON, R. Avaliação Nacional de Alfabetização e suas implicações no cotidiano da escola a partir da visão dos diretores do município de Braço do Norte 2013-2015. Dissertação (Mestrado em Educação). Universidade do Sul de Santa Catarina, Tubarão, 2017.

BOMFIM, M. da S. Práticas comunicacionais na produção de eventos: o texto e o compartilhamento de significados na perspectiva da Escola de Montreal. Dissertação (Mestrado em Comunicação). Universidade Católica de Brasília. Distrito Federal, 2017.

BRASIL. Instituto Nacional de Estudos e Pesquisas Educacionais Anísio Teixeira. Avaliação Nacional da Alfabetização (ANA): documento básico. Brasília: Instituto Nacional de Estudos e Pesquisas Educacionais Anísio Teixeira, 2013 b.

BRASIL. Instituto Nacional de Estudos e Pesquisas Educacionais Anísio Teixeira. Relatório SAEB-ANA 2016: Panorama do Brasil e dos Estados. Brasília: Inep, 2016a.

BRZEZINSKI, I. Fundamentos Sociológicos, Funções Sociais e Políticas da Escola Reflexiva e Emancipadora: algumas aproximações. In: Escola reflexiva e nova racionalidade. ALARCÃO, I. (org.). Porto Alegre: Artmed, 2001. 
DIAS, E. T. G. Provinha Brasil e Regulação: implicações para organização do trabalho pedagógico. Tese (Doutorado em Educação). Universidade Federal de Brasília, Distrito Federal, 2014.

FERNANDES, R.C.A. Educação continuada de professores no espaço-tempo da coordenação pedagógica: avanços e tensões. In: VEIGA, I. P. A; SILVA, E. F. (orgs.). A escola mudou que mude a formação de professores. Campinas, São Paulo: Papirus, 2010.

FERREIRA, E. B; OLIVEIRA, D. A. (org.). Crise da escola e políticas educativas. 2.ed. Belo Horizonte: Autêntica Editora, 2013.

FREITAS, L.C. de [et.al.]. Avaliação Educacional: caminhando pela contramão. Rio de Janeiro: Vozes, 2009.

FREITAS, R. A.M da M; LIBÂNEO, J. C; SILVA, E. Políticas educacionais baseadas em resultados e seu impacto na qualidade do ensino: a visão de professores e gestores sobre a reforma educacional no Estado do Goiás. SILVA, S.P. Reforma educacional goiana: desdobramentos no currículo e nas práticas educativas. In: Políticas educacionais neoliberais e a escola pública: uma qualidade restrita de educação escolar (livro eletrônico). LIBÂNEO, J. C.; FREITAS, R. A. M. da M. (Orgs.). 1. ed. Goiânia: Editora Espaço Acadêmico, 2018, pp. 88-130.

GENTILI, P. A. A.; SILVA, T. T. Neoliberalismo, qualidade total e educação: visões críticas. 8. ed. Petrópolis: Vozes, [s.d.].

GIROUX, H. A. Alfabetização e a pedagogia do empowerment político. In: FREIRE, Paulo; MACEDO, Donaldo. Alfabetização: leitura da palavra leitura do mundo. trad. Lólio Lourenço de Oliveira. Rio de janeiro: Paz e Terra, 1990.

IBGE, 2017. Disponível em: <https://agenciadenoticias.ibge.gov.br/agencia-noticias/ 2012-agencia-de-noticias/noticias/21255-analfabetismo-cai-em-2017-mas-segue-acima-da-meta-para-2015> Acesso 13/11/2018.

LIBÂNEO, J. C. Organização e gestão da escola: teoria e prática. 5. ed. revista e ampliada. Goiânia: Alternativa, 2004.

LIBÂNEO, J. C.; FREITAS, R. A. M. da M. A pesquisa: repercussões de políticas educacionais na escola e na sala de aula. In: Políticas educacionais neoliberais e a escola pública: uma qualidade restrita de educação escolar (livro eletrônico). LIBÂNEO, J. C.; FREITAS, R. A. M. da M. (Orgs.). 1. ed. Goiânia: Editora Espaço Acadêmico, 2018.

LIBÂNEO, J. C.; OLIVEIRA, J. F. de. TOSCHI, M. S. 10.ed. Educação escolar: políticas, estrutura e organização. São Paulo: Cortez, 2012. 
LÜCK, H. Perspectivas da Avaliação Institucional da escola. Petrópolis: Vozes, 2012.

LIMA, E. S. O diretor e as avaliações praticadas na escola. In: SOUSA, J. V de. (org.). Políticas de educação no Distrito Federal: evolução e perspectivas. Brasília: Liber Livro, 2012.

MAINARDES, J. Reinterpretando os Ciclos de Aprendizagem. São Paulo: Cortez, 2007.

MARIOTTI, H. Os operadores cognitivos do pensamento complexo. In: Pensamento Complexo: suas aplicações à liderança, à aprendizagem e ao desenvolvimento sustentável. 2.ed. São Paulo: Atlas, 2007.

MENDES; G. do S.C. V; CARAMELO, J.; ARELARO, S. R. G., et. al. Revista Educação e Pesquisa, v.41, n. especial, pp.1283-1296, dez.2015.

MORAES, R. Uma tempestade de luz: a compreensão possibilitada pela análise textual discursiva. Ciência \& Educação, v. 9, n. 2, pp. 191-211, 2003.

MORAES; R. GALIAZZI, M. do C. Análise Textual Discursiva. 3.ed.rev.ampl. Ijuí: Ed. Unijuí, 2016.

MORIN, E. Introdução ao Pensamento Complexo. Trad. Eliane Lisboa. 4. Ed. Porto Alegre: Sulina, 2011.

NETO, H. Avaliação externa de escolas e sistemas: questões presentes no debate sobre o tema. R. bras. Est. pedag., Brasília, v. 91, n. 227, pp. 84-104, jan./abr. 2010.

OVANDO, N. G; FREITAS, D. N. T. Desdobramentos locais da política nacional de promoção da qualidade do Ensino Fundamental. Intermeio: revista do Programa de Pós-graduação em Educação, Campo Grande, MS, v. 17, n. 34, p. 110-132, jul./dez. 2011.

PARO, V. H. Gestão Democrática da escola pública. São Paulo: Cortez, 2017.

PERRENOUD, P. Os ciclos de aprendizagem: um caminho para combater o fracasso escolar. Porto Alegre, Artmed, 2007.

PESSONI, L. M de L.; LIBÂNEO, J. C; Finalidades da educação escolar e critérios de qualidade de ensino: as percepções de dirigentes escolares e professores. In: Políticas educacionais neoliberais e a escola pública: uma qualidade restrita de educação escolar (livro eletrônico). LIBÂNEO, J. C.; FREITAS, R. A. M. da M. (Orgs.). 1. ed. Goiânia: Editora Espaço Acadêmico, 2018. 
RAMOS, M.P. SCHABBACH, L.M. O estado da arte da avaliação de políticas públicas: conceituação e exemplos de avaliação no Brasil. Revista de Administração Pública. Rio de Janeiro, pp. 1272-1294, set/out, 2012.

SECRETARIA DE ESTADO DE EDUCAÇÃO DO DISTRITO FEDERAL. Currículo em Movimento da Educação Básica Ensino Fundamental Anos Iniciais. Brasília: SEEDF, s/d. Disponível em http://www.se.df.gov.br/curriculo-em-movimento-da-educacao-basica-2/. Acesso em 10 dez. 18.

SILVA, S.P. Reforma educacional goiana: desdobramentos no currículo e nas práticas educativas. In: Políticas educacionais neoliberais e a escola pública: uma qualidade restrita de educação escolar (livro eletrônico). LIBÂNEO, J. C.; FREITAS, R. A. M. da M. (Orgs.). 1. ed. Goiânia: Editora Espaço Acadêmico, 2018, pp. 131-150.

SOLIGO, V. A ação do professor e o significado das avaliações em larga escala na prática pedagógica. In: WERLW, F. O. C. (org.). Avaliação em larga escala: foco na escola São Leopoldo: Oikos; Brasília: Liber Livro, 2010, pp. 119 - 146.

TARDIF, M. Saberes docentes e formação profissional. 17. ed. Petrópolis: Vozes, 2014.

VIEIRA, S. L. Educação Básica: política e gestão da escola. Brasília: Liber livro, 2009.

\section{DADOS DOS AUTORES}

\section{Thamara Maria de Souza}

Mestre em Educação pelo Programa de Pós-Graduação em Educação da Universidade Católica de Brasília (PPGE/UCB).tmasouza@hotmail.com.br

\section{RoBSON DiAS}

Jornalista, mestre e doutor em Comunicação. Docente do Programa de Pós-Graduação em Educação da Universidade Católica de Brasília (PPGE/UCB).rbsn.dias@gmail.com

Submetido em: 10-03-2020

Aceito em: 01-02-2021 